\title{
Development of multilingual education in Ukraine
}

\author{
Nina Nikolska ${ }^{1, *}$, and Oksana Pershukova ${ }^{2}$ \\ ${ }^{1}$ National University of life and environmental sciences of Ukraine, 15 Heroiv Oborony Str., Kyiv, Ukraine \\ ${ }^{2}$ National Aviation University, 1 Lubomyra Guzara Ave., Kyiv, Ukraine
}

\begin{abstract}
Language education is an important tool that forms the consciousness of the individual and its ability to be socially mobile in society, contributes to a dialogue of cultures in a globalizing world. New realities require changes in the definition of the level of knowledge of foreign languages, the new approaches definition to the selection of content and organization of materials, the use of adequate forms and types of control. Of particular relevance is multilingual education on the principle of Ukrainian + foreign in the light of Common-European polymeric trends, the integration of our state in the European educational space, the spread of student exchange practices and the openness of our country's educational system for foreign students. The spread of the foreign languages studying fits into the context of European directives, which recommend that the Member States teach two other languages of the European Union in educational institutions, in addition to the state language. Multilingual education in Ukraine is an adequate answer to the question of linguistic and cultural diversification in Europe. An important feature of multilingual education in Ukraine is to take into account the regional needs of local ethnic communities, national characteristics and Common European trends.
\end{abstract}

\section{Introduction}

\subsection{The problem statement}

A characteristic feature of modernity is the increase in the scale and pace of change due to the information society formation. Priority is currently given to information, high technology and humanistic principles of governance, based on democratic public decisionmaking. The information community is characterized by the globalization of processes and phenomena that form a single world and a single information space. This contributes to the establishment of a single global culture of mankind, as well as the interpenetration and enrichment of national cultures [1].

The interconnectedness and interdependence of countries and nations of the modern world, the intensive development of globalization processes determine the growth of interest in studying international experience in public life's various areas, including the activation of international comparative studies in the educational sphere. Education reforms constitute an important aspect of European countries' social policies. The main trends analysis in the development of the theory and practice of education in the modern world to search for new educational models that meet the requirements of our time is the study object of comparative pedagogy. In the context of this scientific direction, there are many views of scientists on the substantiation of trends in the development of the world and European education in the 21 st century [2], however, they are very cautious in making forecasts and warn that their assumptions may be erroneous, since the future is multivariate, and social and pedagogical processes are largely unpredictable, and only time will adequately demonstrate the truth or falsehood of one or another prognostic the script.

\subsection{Literature review}

According to the Ukrainian researcher O. Lokshyna, the trend is the basic category of comparative pedagogy [3]. Therefore, we dwell on the essential characteristics of this term in more detail. The trend - (from the Latin "tendo" - "I direct, I want") means the direction of development, a manifest opportunity, which under certain conditions turns into reality [4]; Collins English Dictionary suggests viewing the trend as a tendency to a specific characteristic, or a general course [5], and the Macmillan electronic dictionary provides such a translation: 'something will likely happen'. A trend as a category of comparative pedagogy (according to N. Lavrychenko) serves as a form for determining patterns that, on the whole, have no other reality than approaching something in a trend. O. Lokshyna interprets the concept of tendency not only from the position of revealing the direction of movement but also in the context of the essence of qualitative changes occurring during this movement [3]. A. Sbruyeva sees the conditioning of trends in education by its functions, the implementation of which can have the result of both favourable and unfavourable external socio-cultural conditions. At the same time, A. Sbruyeva draws attention to the contradictions that arise in educational systems: between global and local problems, between traditions and modernism, between competition in achieving success and aspirations for equal

\footnotetext{
*Corresponding author: nina777-07@,hotmail.com
} 
opportunities. Therefore, awareness in the areas of educational trends provides the basis for forecasting and updating, increasing the level of integrity. A. Ohienko refers to the implementation of educational trends 'as a result of the contradictory interaction of the determining force of laws of the internal structure, functioning and development of the educational sphere on the one hand, and external factors due to the impact on the educational integrity of other cultural subsystems - from the others' [6, p. 380]. Consequently, the trend in comparative pedagogy is the educational changes direction, due to the numerous political, social, cultural and scientific factors that interact in society, often causing contradictions, and result in the emergence of a new quality of educational processes. The trend is based on a set of ideas and aspirations, and therefore its manifestations can cause a confrontation of interests, which results in the strengthening or weakening of some processes, changes in educational policy or practice at a certain level depending on the direction and intensity of society development. The work of the comparativists and a detailed analysis of the directions of educational changes development in foreign countries, their intensity levels, and the interaction results, is a prerequisite for predicting the further development of the educational direction and developing proposals for updating the domestic school. In the multilingual education of schoolchildren in Western European countries, the trend personifies the direction of pedagogical phenomena development aimed at developing students' ability to communicate in several languages, as well as possession of a complex of knowledge, skills, experience, and attitudes that are part of intercultural competence. This development direction is the result of political, economic, socio-cultural and ethnolinguistic processes in Europe and the world, as well as in any of the Western European countries where training takes place, but regional, local and individual development levels are also significant. Because of the above mentioned, the European and global trend in the development of multilingual education has largely influenced the development of multilingual education in Ukraine.

\subsection{Methods}

The purpose of the article is to highlight the main directions of pedagogical research in the field of multilingual and bilingual education through the analysis of the achievements of Ukrainian researchers in the field of pedagogy. The methodological basis of the study was an analysis of published texts, a comparison of their content, the synergistic approach to their interpretation, combined to make possible conclusions.

\section{Multilinguaism forming}

\subsection{Bilingual education in Ukraine}

The concept of 'native language' is not unambiguous, as it seems at first glance. For many people, the mother tongue is one that a person has the best of and which is fundamental to her/his communication. This is the language of her 'kind', having deep roots in her native land. Such a model of linguistic, personality cultural development is common, but it is not the only one. In the ethnic reference book, which refers to linguistic, sociological terms, it is stated that 'atypical options for the formation of the child's speech in the mass migration context, high territorial and social mobility of people are becoming more common and require a clear definition of their native, maternal, ethnic, functionally first language' [7, p. 15-17].

Local scientist I. Hydzuk on this occasion notes that the reality for our country is a huge variety of conditions, situations that do not fall into any categorical formula. So, in Ukraine there are various population groups:

- Ukrainians, who learned their language from their father and mother, actively use it in all spheres of life and consider it undoubtedly native, and speak Russian poorly;

- Ukrainians, for whom the Ukrainian language is the mother language, but they studied in a Russian-language school, after graduation spoke Russian in many fields as official, and speak it better than Ukrainian;

- bilingual immigrants from families where parents are representatives of different nationalities, but for one of the parents Ukrainian is their native language;

- Russians who have accepted the Ukrainian idea and speak two languages;

- Russians who, according to national identity, remain Russian and speak mostly Russian, although they are patriots of Ukraine.

The researcher also mentions the facts about known cases of Ukrainian native language rejection, which is perceived as non-prestigious [7, p. 17-18].

The development of Ukraine as a multinational state, the formation of a civil democratic society opened to other countries, peoples, and cultures, as well as the process of general secondary education transformation in the context of society globalization, requires the new approaches development to teaching the younger generation in the context of the revival of ideas of national and multicultural education. Among the main tasks set for modern education in Ukraine is the preparation of young people for life in a multicultural, globalizing society. Of particular importance in educational activities is the formation of the ability to conduct a productive dialogue, including a foreign language, with representatives of other countries, cultures, nations [8, p. 9-10].

The present of our country is characterized by two interconnected development trends: the strengthening of Ukraine as an independent state and its integration into global processes, in particular in the European educational space. For Ukraine, entering the mentioned space means focusing on state-public management principles; increasing the role of alternative systems and innovative processes; widespread introduction into all links of new, first of all, information technologies; ecological and cultural orientation of education and science; providing citizens with the right to choose equal conditions for general education, access to science, regardless of their socio-genetic capabilities; moral and spiritual improvement of citizens; ensuring the 
continuity of personality education throughout life $[8$, p. 9-10].

The process of Russification of Ukrainian population lasted for several centuries. Therefore, the process of the state Ukrainian language strengthening is developing so slowly and not easily. Local specialist in the field of bilingual education L. Tovchyhrechka identifies eight main stages of the development of 'Ukrainization' in Ukraine.

The first stage (1922-1929) went down in history as the policy of 'Ukrainization'. The beginning of Ukrainization in the publication of the following documents: Decree of the Council of People's Commissars of the Ukrainian SSR of July 27, 1923 'On Measures in the Case of Ukrainization of Schools and Teaching and Cultural-Educational Institutions' and Decree of August 1, 1923 'On Measures to Ensure Equality of Languages and on Assisting the Ukrainian Language Development'. In 1929, training in the Ukrainian language was carried out by more than $80 \%$ of secondary schools, over $75 \%$ of technical schools and $30 \%$ of institutes [9].

The second stage (1930-1952). Assimilation policy in the practice of language planning in the USSR. The crowding out of national languages into Russian took place by spreading it in the status of a language of interethnic communication with a gradual increase in National-Russian bilingualism within national collectives; in the future, monolingualism should end in Russian.

The third stage (1953-1958). The Soviet government, under the leadership of Khrushchev, developed a program to accelerate the Russification of non-Russian peoples of the Soviet Union. The law on the free choice by parents of the instruction language and on permission to refuse to study the Ukrainian language.

The fourth stage (1958-1962) was characterized by the emergence of the theory of 'the promising and unpromising language'. In the early 60 s of XX century, a scientific council was created in the system of the USSR Academy of Sciences on the problem of 'Patterns of the Development of National Languages in Connection with the Socialist Nations Development,' the orientation of which was clearly illustrated by its program published in the journal Questions of Linguistics (1962). The main task of the council was to create a theoretical base for the forced Russification of several republics. On this basis, the peoples' languages of the USSR were divided into promising and unpromising. The first ones included, of course, 'the great Russian language', Armenian, Georgian, Latvian, Lithuanian and Estonian. Other languages fell into the category of unpromising. Thus, the Ukrainian and Belarusian languages, as well as the Azerbaijani language and the speeches of the Central Asian republics, were excluded from the promising group.

The fifth stage (1963-1975). Dissemination of the theory of 'objective rapprochement of nations', which provided for the infusion of closely related languages into the Russian language. During this stage, the Russification of all life spheres - education, science, production, the media, culture - was noted with particular intensity.

The sixth stage (1975-1985) is determined by the substantiation of the concept of a single Soviet people. During this period, the crowding out of the Ukrainian language of higher education and science intensified. The language of instruction in vocational schools and higher educational institutions has become Russian. The Russification linguistic and cultural policy in all areas of public life has led to the fact that in the east and south of the Ukrainian SSR the Russian language has finally changed its native language in the field of scientific communication. All this led to a sharp narrowing of the functioning of the Ukrainian language in most of Ukraine and the decline in its prestige. At the end of the $70 \mathrm{~s}$, the assimilating influence of the Russian language in eastern and southern Ukraine turned over from city to village.

The seventh stage (1985-1990) is characterized by the idea of harmonious National-Russian bilingualism. At this time, the development of the scientific program 'The Role of the Russian Language as a Means of Interethnic Communication' significantly increased.

The eighth stage (1991-2015) - the formation of language policy in Ukraine [9, p. 157-160].

Multilingualism is a feature of the national structure of the population of Ukraine. According to the AllUkrainian Population Census of 2001. Representatives of more than 130 nationalities and ethnic groups live in Ukraine. The number of representatives of the titular nation is $77.8 \%$. The second largest group is the Russians, their number is $17.3 \%$. Other ethnic minorities: Belarusians (0.6\%), Moldavians (0.5\%), Crimean Tatars $(0.5 \%)$, Bulgarians $(0.4 \%)$, Hungarians $(0.3 \%)$, Romanians $(0.3 \%)$, Poles $(0.3 \%)$, Jews $(0.2 \%)$, Greeks $(0.2 \%)$, Tatars $(0.2 \%)$, Georgians $(0.1 \%)$, Gypsies $(0.1 \%)$, Azerbaijanis (0.1\%), Germans (0.1\%), Gagauz (0.1\%) [10]. These data indicate a difficult language situation in the country, which is further complicated by the specific sociolinguistic status of the Ukrainian language. It is fixed at the legislative level as the state one, the Ukrainian language is actually in a weak position, especially in large cities in the east of the country - it is the Russian language that dominates. Ukrainian-Russian bilingualism is observed on the prevailing territory of the country, and in some regions, the state language is a minority language, because most ethnic Ukrainian and other nationalities are Russianspeaking. An attempt to determine the language balance, or the real ratio of the two most common languages Ukrainian and Russian - in various spheres of public and private life based on statistical and sociological data, was made by A. Medvedev, vice president of the Ukrainian League for Public Relations. The main conclusions are as follows: Ukraine as a whole is a bilingual state, in which the largest group are exclusively Ukrainianspeaking citizens, and somewhat smaller are two approximately identical groups of bilingual and exclusively Russian-speaking. However, bilingual is mainly ethnic Ukrainians and those who consider Ukrainian their native language. Ethnic Russians and those who call Russian their native language, are part of 
the monolingual. Besides, $15 \%$ of ethnic Ukrainian consider their native language Russian, and $20 \%$ of ethnic Ukrainian communicate exclusively in Russian. A significant number of citizens of non-Ukrainian and nonRussian nationalities, and among some ethnic groups the vast majority, consider the native language Russian, and not the language of their nationality. The fact that the ratio of the speakers of Ukrainian and Russian languages does not correspond to the ratio of ethnic Ukrainian and Russian indicates the deformation of the linguistic situation in Ukraine [11].

Since Independence gaining multilingual education in Ukraine was developing according to two main models: 1) secondary education for children from families of the majority of the population and 2) secondary education for children from families of national minorities. The initial conceptual provisions that determine the content and organization of language education in Ukraine and the legal basis for the formation of state policy to ensure the rights of national minorities are the Declaration on State Sovereignty of Ukraine, the Constitution of Ukraine, Laws of Ukraine 'Based on State Language Policy' (2012), 'on the Concept of State Language Policy' (2010), 'On national minorities in Ukraine’ (No. 2494-XII of 06/25/1992), 'On ratification of the European Charter for Regional languages or minority languages' (No. 804-IV of 05/15/2003), 'On Education' (No. 1144-XII of 06/04/1991), 'On General Secondary Education' (No. 1642-III of 04/06/2000) and other legislative acts of Ukraine. These documents ensure the right of national minorities to meet educational needs in their native language, preservation, and ethnic culture development. At the same time, the need to create conditions for the proper mastery of the state language in secondary schools with instruction in the languages of national minorities is emphasized [12]. The Law of Ukraine 'On National Minorities in Ukraine' regulates the right of all national minorities to use and study their mother tongue in state education all institutions or through national cultural societies [13].

The Law of Ukraine 'Based on State Language Policy' (2012) applies to 18 languages: Russian, Belarusian, Bulgarian, Armenian, Gagauz, Yiddish, Crimean Tatar, Moldavian, German, modern Greek, Polish, Roma (Gypsy), Romanian, Slovak, Hungarian, Ruthenian, Karaime and Crimean. The law contains an ambiguous definition of the term 'mother tongue', interpreting it as follows: 'mother tongue is the first language that a person mastered in early childhood'. According to the conclusions of the Main Scientific and Expert Directorate of the Verkhovna Rada of Ukraine, the definition of the term 'native language' in the law is inaccurate and incorrect, since it follows from the conclusion that the native language can be someone else's speech if, in certain circumstances, a person has mastered it first. It underlines that free choice of the language instruction is an inalienable right of citizens of Ukraine, which is implemented under this Law, subject to the mandatory study of the state language in an amount sufficient to integrate into Ukrainian society. Citizens of Ukraine are guaranteed the right to receive education in the state language and regional or minority languages. This right is ensured through a network of preschool child care facilities, general secondary, extracurricular, vocational and higher state and communal educational institutions with Ukrainian or other languages of instruction, which is created following the needs of citizens and under the legislation of Ukraine on education [11]. The law establishes that the state language is Ukrainian, but significantly expands the use of regional languages if the number of speakers of these languages is at least $10 \%$ of the population in a certain region and some cases less than $10 \%$ [11].

Introduction of a sectoral programme on improving the Ukrainian language teaching in secondary schools (Ministry of Education and Science of Ukraine Order No. 461 of 28 May 2008) began a step-by-step transition to teaching in Ukrainian from the fifth grade onwards the following subjects: history, geography, labour training and physical culture. The elements of bilingual education have been decided to apply by combining the possibilities of the invariant component (in the language of the national minority) and the variable component (in the state language). The specifics of such training are set out in the methodological recommendations. Based on the analysis, we have identified the characteristic features of bilingual education in Ukraine: 1) preliminary acquaintance with separate language units (separate words, word combinations, sentences) and on such basis to offer work with a fragment of the text or the whole text; 2) considerable attention is paid to terminology mastering, words of terminological and general meaning used in various syntactic constructions, word combinations in the subject content - formation of skills to use terms and describe processes; 3) attraction of pupils to all kinds of speech activity in the target (Ukrainian) language in subject lessons, development of both receptive and productive skills, attention is paid to the development of both monological and dialogic speech; 4) regular independent work, work in pairs and groups is provided; 5) in the content of teaching the Ukrainian language improvements are made, as attention is paid to mastering the special vocabulary used in the lessons of the natural and mathematical cycle (numerals, adjectives, adverbs, participles), the formation of skills of terminology using in subject contents for the development of language knowledge (e.g. sound analysis).

According to the Act 'On general secondary education' and Cabinet of Ministers Decision No. 1392 of 23 November, 2011 on the approval of the State standard for basic and complete general secondary education, new model curricula for general education institutions of the second degree have been developed (Ministry Order No. 664 of 29 May 2014). Therefore, in $2014 / 15$ there was a return to the system whereby the institution and parents have the right to choose whether or not to study a second foreign language. According to the new rules, the compulsory study of a second foreign language has been introduced. It can be any foreign, Russian or any other language of a national minority. The school administration became deprived of the right to decide whether to introduce or discontinue the study 
of a particular foreign language alone. All proposals must be discussed and agreed upon with the parents and approved by the teachers' council, provided that appropriate staffing is available. The above mentioned caused the appearance of a third specific model of multilingual education in Ukraine. According to this model the Russian language, usually, the language used in the family of a schoolboy or a schoolgirl is studied as a second foreign language. As the analysis shows, there is no such model in Western European countries. The introduction of such a model in Ukraine corrected the situation in which schoolchildren (Ukrainians by nationality) communicate in everyday life and family environment in Russian, and remain semi-literate because of the lack of this language in the curriculum. The reasons for this situation are caused by, first of all, the deformation of the language situation in Ukraine, the weak position of the Ukrainian language in the society of the country, the relatively close kinship of the Ukrainian and Russian languages, the prevalence of Russian language in Europe and the world. Common problems for all these models are lack of a sufficient number of quality educational programmes, properly developed teaching and methodological materials and methods for consistent teaching of several languages; lack of systematic professional training and professional development of teachers who are ready to teach several languages and cultures or subject content in two languages (state + foreign, national + state); limited number of topics in the curricula dedicated to introducing the languages and cultures of national minorities to the public.

As a result of situation analysis, we have concluded that multilingual education in Ukraine develops according to three main models: the first - multilingual education for children from the families of the majority of the population; the second - multilingual education for children from families of national minorities; the third model of multilingual education is specific; a similar model does not exist in Western Europe. In its context, the Russian language, usually the language used in the student's family, is studied as a second foreign language. The reasons for this state of affairs lie in historical and socio-cultural aspects. Among them is the policy of Russification for a long period of Ukrainian history [14].

So, language education in Ukraine went the hard way, which was significantly influenced by historical events, ideological settings, socio-cultural conditions and many more. Today in Ukraine there is a system of continuous language education, supported by the language policy of the state, aimed at mastering the mother tongue of every speaker, the compulsory mastery of the state Ukrainian language by all citizens (regardless of nationality, religion, social production sphere) and knowledge of foreign languages, as well as language tolerance education.

\subsection{Multilingual education in Ukraine}

The development of secondary education for the first model includes teaching the native students of the Ukrainian language and teaching one or two foreign languages. This model has extensive experience in functioning in the context of specialized schools with the training of several subjects in a foreign language, which is now implemented in the organization of teaching foreign languages to specialized subjects. As emphasized in the White Paper ..., among the shortcomings of this model is the tendency to make the Ukrainian-speaking part of the population monolingual, since in many schools with the Ukrainian language of instruction, only Ukrainian and one foreign language are studied, the level of knowledge of which is low and does not give reason to speak about bilingualism in the Ukrainian system education [15, p. 28-29]. In many schools, until recently, only one foreign language was studied. Therefore, the foreign-language proposal was quite disproportionate the mass learning of English, a small amount of German and a rather insignificant share of French and Spanish. Some specialized schools suggest two foreign languages (English-German, English-French). Cases of learning other foreign languages in schools (Japanese, Chinese, Polish, Hungarian, Czech) are single and often experimental. Besides, training sometimes is hampered by an insufficient level of methodological training of teachers, a poor focus on modern communicative techniques, a lack of real practice and modern teaching aids, in particular, multimedia.

Starting from the academic year 2012-13, compulsory foreign language learning from the first grade and compulsory second foreign language learning from the fifth grade were introduced in the following language combinations: English (IM1) + German (IM2) English (IM1) + French (IM2) German (IM1 ) + English (IM2) French (IM1) + English (IM2), "language of the neighbouring country" (IM1) + English (IM2). So far, such training is largely unorganized, as V. Hamanyuk notes, the correct formation of multilingual competence requires intensification of the educational process, a high level of systematization and abstraction, which should result in a more conscious and deeper understanding of linguistic phenomena, transfer of knowledge and skills in the field of study a new language and the linguistic abilities development: verbal intelligence, language flexibility, language memory, and linguistic intuition. This means that the implementation of the conceptual foundations of multilingual education in Ukraine, defined in the White Paper ... as 'developing models of language education taking into account the sequence of content and teaching methods at certain stages, the correlation of different language courses ... the introduction of bilingual education' is slow enough.

The study of the state language by representatives of national minorities is a prerequisite for the inclusion of ethnic community representatives in the public life of the state since the educational, socio-cultural and economic prospects of the individual depend to a large extent on this kind of competency. The right to learn the official language of a country is part of the language of human rights. Ukrainian is studied as the state language in all educational institutions of Ukraine without exception, and the right of national minorities to meet the educational needs in their native language, the preservation, and development of ethnic and cultural characteristics of representatives of national minorities is 
ensured. In general, in Ukraine, only 31 languages are studied at schools, including 19 languages of national minorities, and Ukraine is one of the few countries in the world where teaching is conducted in eight languages of national minorities. Education of students from families of national minorities is the second model of secondary education in Ukraine. This system was created over the years of independence from scratch. Our state as a whole fulfils its obligations under the Council of Europe, in particular, are provided for by the European Charter for Regional Languages and the Framework Convention for the Protection of National Minorities [16]. However, the intentions outlined in the documents do not always coincide with real opportunities in ensuring educational rights and often have a declarative character. Although during the years of independence in Ukraine in general educational institutions with instruction in the national minorities languages, conditions have been mainly created for the proper mastery of the state language, however, there are certain problems in teaching the Ukrainian language at schools, in particular with the Hungarian and Romanian languages of instruction on the organization of the educational process and methodological support. Since the introduction of teaching the Ukrainian language was begun only after Ukraine gained independence, this process was accompanied by the urgent creation of scientific and methodological centres, the primary tasks of which were the programs and textbooks creation. The authors' lack of theoretical training on the problems of selecting the content and methodology of language teaching affected the quality of instruction: the programs were imperfect, the textbooks were created without taking into account the sociolinguistic situation and the sociocultural characteristics of minorities, and therefore often had a compilation character. Also, the textbooks for primary and high school contained too much theoretical material and were similar to textbooks for schools with the Ukrainian language of instruction. Another problem was the ratio of the components of education in the mother tongue and the state language - it was disproportionate at all levels of education: in the elementary school, out of the total weekly load of 85 hours, only 14 are devoted to mastering the state language, in the primary school, 155 versus 22 in the senior school [17].

In recent years, a tendency toward mastering foreign languages has been observed in Ukraine more and more transparently, they are actively acquiring the status of a socio-economic and political means of understanding between various representatives of the world community in various spheres of life. These realities objectively determine the expansion of the functions of foreign languages and the renewal of the tasks of mastering them in modern society. First of all, it is:

- formation of readiness for social interaction among pupils/students to jointly solve various problems and to achieve mutual understanding compromises;

- tolerant attitude towards the peoples whose language is studied, familiarization with the dialogue of cultures as an important phenomenon of peaceful coexistence and mutual enrichment;
- mastering the techniques of independent work with the language, learning strategies, the ability to use compensatory techniques in case of language resources shortage;

- creative use of a foreign language for their expression, awareness of language differences with their native language, knowledge, and ability to use the features of its use in typical social communication situations;

- the formation by pupils/students of an individual learning style, self-control of their level of mastery of foreign language communicative competence[14].

The result of language training should be personal multilingualism (plurilingualism), which provides for a deliberate differentiation of language systems and a relatively free transition from one language to another, depending on the changing situation and needs.

\section{Conclusions}

As a result of our research, we have concluded that historical events, ideological settings, socio-cultural conditions and many other factors influenced greatly on the language situation and language education in Ukraine.

The development of multilingual education in different countries of the world and Ukraine as well has become a requirement of time. Multilingual education in Ukraine is developing according to three main models: the first - multilingual education for children from the families of the majority of the population; the second multilingual education for children from families of national minorities; the third model of multilingual education is specific; a similar model does not exist in Western Europe. In its context, the Russian language, usually the language used in the student's family, is studied as a second foreign language. The reasons for this state of affairs lie in historical and socio-cultural aspects. Among them was the policy of Russification for a long period of Ukrainian history and which resulted in the deformation of the language situation in modern Ukraine.

Based on the study results, proposals on the development of multilingual education of schoolchildren in Ukraine are substantiated. Their main directions can be represented at several levels. At the conceptual level: to improve the conceptual foundations of multilingual education, taking into account Western European experience and national characteristics, the requirements of the labour market and Ukrainian society. At the educational and administrative level: to provide support for educational initiatives to develop multilingualism at the regional and local levels to preserve the existing linguistic and cultural heritage and subsequent integration into the European and world educational space; to develop and ensure the implementation of the state language policy in the education system, taking into account regional characteristics; create a sufficient number of high-quality educational programs for various levels of education, taking into account the kinship / non-recognition of languages; to contribute to the implementation of the teaching English experience as a language of worldwide communication; to improve the system of professional training and teachers' 
professional development, to provide training for bilingual specialists or those who are ready to teach not only two languages as systems, but also subject content in two languages (state + foreign, national + state) with experience in a multicultural environment. At the scientific and methodological level: to study the foreign experience of immersion, receptive and other technologies of multilingual education and to test them experimentally in the conditions of the Ukrainian school. At the school level: encourage the diversification of language learning in schools; introduce the process of integration of the curriculum in language subjects as a way to avoid competition and rivalry, increase the cooperation level, collegiality and mutual assistance among teachers of language subjects; provide methodological support from school administration and academic institutions. At the individual level: to promote the development of language abilities based on individualization, learning process differentiation; to apply the students' experience of learning languages, use the already existing metalinguistic consciousness; to learn to apply various strategies, to form a habit and need for students to master the languages throughout their lives [14].

Implementation of the proposals will contribute to the formation of responsible citizens of Ukraine, capable of thinking globally, ready to live and work next to representatives of different peoples and cultures. Improving the process of forming the individual multilingualism (plurilingualism) of young Ukrainians will contribute to the preservation of their cultural identity and the development of their creative potential, provide an opportunity for professional mobility, will be an effective means of supporting political stability in society.

\section{References}

1. T. Petrova, Tendencii razvitija sovremennogo obrazovanija (Trends in the development of modern education). Observer 2(193) (2006)

2. Z. Kolokol'nikova, Vedushhie tendencii razvitija sovremennogo mirovogo obrazovatel'nogo processa (Leading trends in the development of the global educational process). Dinamika sovremennoj nauki (2012),

http://www.rusnauka.com/21_DSN_2012/Pedagogic a/4_114364.doc.htm. Accessed 16 Sept 2019

3. O. Lokshyna, Tendenciya yak katehoriya porivnyal'noyi pedahohiky (Trend as a category of comparative pedagogy). Comp. ped. stud 8 (2011), http://lib.iitta.gov.ua/7118/1/18585-27831-1SM.pdf. Accessed 27 Jan 2019

4. Ukrainian Dictionary: Academic Interpretative Dictionary (1970-1980), http://sum.in.ua/s/tendencija. Accessed 26 Feb 2015

5. Collins English Dictionary, http://www.collinsdictionary.com/dictionary/english /tendency. Accessed 26 Feb 2015

6. O. Ohienko, Trends in Adult Education in Scandinavian Countries (Ellada, Sumy, 2008).
7. I.F. Hudzyk, Competently-oriented teaching of the Russian language in elementary grades (in schools with the Ukrainian language of instruction). (Bukrech, Chernivtsi, 2007).

8. S.M. Nikolaenko, Education and Science: Legislative and Methodological Foundations (Politekhnika, Kyiv, 2004), p. 280

9. L. V. Tovchyhrechka, Dissertation, Sumy Makarenko State Pedagogical University, 2012

10. Proceedings of the 2001 All-Ukrainian Census (2001),

http://2001.ukrcensus.gov.ua/results/general/languag e. Accessed on 10 Feb 2012.

11. Law of Ukraine "On the Principles of State Language Policy" (2012), http://zakon4.rada.gov.ua/laws/show/5029-17. Accessed 16 Sept 2014

12. Law of Ukraine "On Education" (1991), http://zakon1.rada.gov.ua/laws/show/1060. Accessed 16 Sept 2014

13. Law of Ukraine "On National Minorities in Ukraine" (1992). Accessed 16 Sept 2014

14. O.P. Pershukova, Dissertation, Ivan Ziaziun Institute of Pedagogical and Adult Education of the National Academy of Educational Sciences of Ukraine, 2016

15. V.G. Kremen, White Paper on National Education of Ukraine (Acad. ped. of Sciences of Ukraine, Kyiv, 2009)

16. On the Methodological Recommendations of the Ministry of Education and Science on the Application of Elements of Bilingual Learning, Regulatory Letter No. 1/9-581 of 28.08.2009, Information Bulletin of the Ministry of Education and Science of Ukraine (2009). Accessed 16 Sept 2014

17. T. Bodnarchuk, S. Tsura, Osoblyvosti orhanizaciyi bilinhval'noyi osvity dlya ditej nacional'nyh menshyn $\mathrm{v}$ Ukrayini (Peculiarities of balancing education organization for children of national minorities in Ukraine). Bulletin of the University of Lviv 28, 111-121 (2012) 